\title{
Assessment of Hepatitis B and Hepatitis C Virus Infections and Associated Risk Factors among Patients Attended Rwanda Military Hospital
}

\author{
Ange Yvette Uwitonze ${ }^{1}$, Jean de Dieu Tuyishime ${ }^{1}$, Pacifique Ndishimye ${ }^{2}$, William Niyonzima ${ }^{4}$, Jean \\ Marie Vianney Halleluia ${ }^{3}$, Callixte Yadufashije 2* $^{\text {H }^{*}}$
}

${ }^{1} \mathrm{MSc},{ }^{1} \mathrm{BSc}$, Department of Biomedical Laboratory Sciences, INES Ruhengeri-Institute of Applied Sciences, Rwanda ${ }^{2} \mathrm{PhD}$, Department of Biomedical Laboratory Sciences, INES Ruhengeri-Institute of Applied Sciences, Rwanda ${ }^{3} \mathrm{BSc}$, Rwanda Military Hospital

${ }^{4}$ BSc, Department of Biomedical Laboratory Sciences, INES Ruhengeri-Institute of Applied Sciences, Rwanda "Corresponding Author

Dr. CallixteYadufashije

Department of Biomedical Laboratory Sciences and Directorate of Research and consultancy

INES Ruhengeri- Institute of Applied Sciences

Rwanda

Email: cyadufashije@ines.ac.rw cyadufashije@gmail.com

Received:13 August 2019; | Revised:30 August 2019; | Accepted:04 March 2020

\section{Abstract}

Background:Viral hepatitis is an infection affecting the liver and causing its inflammation due to viruses mostly hepatitis $\mathrm{B}$ and $\mathrm{C}$ viruses. Hepatitis $\mathrm{B}$ and $\mathrm{C}$ virus infections are serious global health issue leading to morbidity and mortality worldwide. Hepatitis $\mathrm{B}$ and $\mathrm{C}$ virus can lead to liver damage, liver cirrhosis and liver carcinoma. These infections are serologically characterized by the presence of $\mathrm{HCV}-\mathrm{Ab}$ and HBsAg in serum.

Objectives:The objective was to assess hepatitis $\mathrm{B}$ and $\mathrm{C}$ viral infections and associated risk factors among patients attended Rwanda Military Hospital.

Materials and methods: This was a cross sectional study and was carried out between September 2016 and November 2016. A total of 100 participants were eligible in the research based on inclusion Criteria. $\mathrm{HCV}-\mathrm{Ab}$ and HBsAg were detected using rapid diagnostic tests with immunochromatographic method and positive samples were confirmed using Cobas e411 analyzer, with electrochemiluminescence method. The results for Hepatitis B and C were statistically analyzed using SPSS 16.0.

Results: The results of the present study show that hepatitis $\mathrm{B}$ and $\mathrm{C}$ infections prevalence were high and several risk factors for HCV and HBV were reported. The statistics show that HCV prevalence was higher than that of $\mathrm{HBV}$ with $20 \%$ and $17 \%$ respectively. Age and marital status were the only significant risk factors for Hepatitis $C\left(\right.$ Age $, x^{2}=17.389, d f=3, p=0.001$, Marital status, $\left.x^{2}=11.096, d f=3 p=0.01\right)$. The lack of vaccination against HBV was the only significant risk factor for $\mathrm{HBV}(\mathrm{x}=4.496, \mathrm{df}=1, \mathrm{p}=0.034)$.

Conclusion: There was no Hepatitis $\mathrm{B}$ and $\mathrm{C}$ co-infection among the patients.Several risk factors for hepatitis $\mathrm{B}$ and $\mathrm{C}$ were reported. Education of the population about HCV and HBV infections, screening and vaccination, were urgently recommended in order to prevent and cut down the HBV and HCV infections. 


\section{Introduction}

Viral hepatitis is a systemic infection affecting predominantly the liver and causing its inflammation due to viruses. It may be acute (recent infection, relatively rapid onset) or chronic ${ }^{[1]}$. Viral hepatitis is caused by infection with one of the five known hepatotropic viruses, which are named as hepatitis A virus (HAV), hepatitis B virus (HBV), hepatitis $\mathrm{C}$ virus (HCV), hepatitis D virus (HDV), and hepatitis E virus (HEV), respectively ${ }^{[2]}$.

Hepatitis B virus (HBV) infection causes a spectrum of acute and chronic liver disease, ranging from inactive chronic carrier status to progressive chronic hepatitis, leading to end-stage cirrhosis and primary liver cancer. Worldwide, two billion people have been infected with hepatitis B virus (HBV), 360 million have chronic infection, and 600,000 die each year from HBV-related liver disease or hepatocellular carcinoma ${ }^{[3]}$. In sub-Saharan Africa, over $8 \%$ of the population has chronic HBV carriage with a high risk for progressive liver disease $^{[4]}$.

Hepatitis $\mathrm{C}$ virus (HCV) infection, poses a significant global health problem. In 2012, the world health organization estimated that there are 150 million infected people globally. This accounts for $3 \%$ of the world population and there are variations according to regions, the highest prevalence being in Egypt, 20\% of the word population. This virus of hepatitis $\mathrm{C}$ is a major cause of chronic liver disease, cirrhosis and liver cancer $^{[5]}$.

The pathogenesis of hepatitis $\mathrm{B}$ and $\mathrm{C}$ virus infections is characterized by permanent inflammatory processes that predispose the liver to hepatocellular carcinoma (HCC). HCV is a noncytopathic virus that enters the liver cell and undergoes replication simultaneously causing cell necrosis by several mechanisms including immunemediated cytolysis in addition to other various phenomena such as hepatic steatosis, oxidative stress and insulin resistance ${ }^{[6]}$.

HBV along with the hepatitis $\mathrm{C}$ virus (HCV) can cause broad-spectrum diseases such as hepatitis, fibrosis, cirrhosis and hepatocellular carcinoma (HCC) in the setting of chronic infection ${ }^{[7]}$. HBV is non-cytopathic for infected hepatocytes. Hepatocytes are infected without any evidence of liver injury prior to the recruitment of $\mathrm{HBV}$-specific $\mathrm{T}$-cells into the liver ${ }^{[8]}$. Cytotoxic $\mathrm{T}$ lymphocytes (CTL) have been regarded as the main culprit for liver damage during acute HBV infection ${ }^{[9]}$. During acute HBV infection, HBV-specific CTLs can directly attack infected hepatocytes and participate in the pathogenesis of liver disease by orchestrating diverse components of the immune system. Necroinflammatory liver disease might be caused by secondary recruitment of mononuclear cells ${ }^{[10]}$.

$\mathrm{HCV}$ and HBV infections are serious global health issue leading to morbidity and mortality. Worldwide, 2 billion people (almost 1/3 of word' $\mathrm{s}$ population) were infected by HBV and about 300400 million become chronic carriers ${ }^{[11]}$. About 100 million people are chronically infected with $\mathrm{HCV}$ [12].

Africa has the highest hepatitis $\mathrm{C}$ prevalence (5.3\%). Egypt has the highest prevalence (17.5\%) of hepatitis $\mathrm{C}$ in the world ${ }^{[13]}$. The World Health Organization reports $75 \%$ of $\mathrm{HCV}$-infected individuals developing chronic liver disease. Among those $\mathrm{HCV}$-infected patients who develop chronic liver disease, $1.6 \%$ progress to Hepatocellular carcinoma (HCC), a condition with a mortality rate $>80 \%{ }^{[14]}$. Prevalence of hepatitis B surface antigen (HBsAg) in the general population varies geographically, with the highest rates $(>8 \%)$ measured in West Africa .HBV represents a critical threat to health in the African continent. It causes a spectrum of acute and chronic liver disease, ranging from inactive chronic carrier status to progressive chronic hepatitis, leading to end-stage cirrhosis and primary liver cancer ${ }^{[15]}$.

Currently in Rwanda Hepatitis B prevalence is at $3.6 \%$, which has now exceeded HIV prevalence at 3\%. Particularly, types B and C lead to chronic disease in hundreds of millions of people and are the most common cause of liver cirrhosis and cancer. About $1.6 \%$ of blood donor units are HBV positive each year, while $2.9 \%$ of health care workers (HCWs) were positive in a recent screening study and for hepatitis $\mathrm{C}$ virus infection prevalence is $2.5 \%$. No many population-based studies 
regarding $\mathrm{HBV}$ and $\mathrm{HCV}$ virus, infection are available in Rwanda ${ }^{[16]}$.

associated risk factors among patients attending Kanombe Military Hospital

\section{Materials and Methods}

\subsection{Study design}

This was a cross-sectional study conducted between September 2016 and November 2016. Each participant was screened for hepatitis B surface antigen (HBsAg) and hepatitis $\mathrm{C}$ antibody (HCV-Ab). The suspected patients were explained about the study, its benefits and risks. They signed voluntarily the consent form before responding to questionnaires that were given to them to collect bio-data from each participant. To ensure confidentiality, their data were anonymized.

\subsection{Study population}

The study was carried out at Rwanda Military Hospital (Kigali, Rwanda). The target population was patients of all ages and gender suspected for HBV and/or HCV. 100 participants were recorded and tested for $\mathrm{HCV}-\mathrm{Ab}$ and $\mathrm{HBsAg}$.

\subsection{Blood sample collection and laboratory diagnosis}

$4 \mathrm{ml}$ of peripheral venous blood was collected from each suspected patient, in a red top tube with clot activator. Blood samples were centrifuged using Humax $14 \mathrm{k}$ centrifuge with 3000 rounds/min for 5 minutes to get serum. Rapid diagnostic tests were used for $\mathrm{HCV}$ and $\mathrm{HBV}$ screening. A rapid anti-HCV (Cypress Diagnostics) with a sensitivity of $95.3 \%$ and specificity of $98.7 \%$ and One step Alere Determine HBsAg test (Alere Inc, Waltham, M.A., USA) with $96 \%$ sensitivity and 98\% specificity that are immunochromatographic qualitative tests, were used to detect $\mathrm{HCV}-\mathrm{Ab}$ and HBsAg respectively. All positive samples after the use of RDTs, were analyzed using electrochemiluminescence immunoassay (Cobas e411, Roche Diagnostics, Mannheim, Germany) \& ELISA for confirmation. Prior to the run of the tests, calibrators and controls were run to be sure for the
The overall aim of this study was to assess the the frequency of HCV and HBV and their reliability of the results got. The cut-off index values below one $(\mathrm{COI}<1)$ were considered negative and those above one $(\mathrm{COI}>1)$ were considered positive.

\subsection{Statistical analysis}

After data collection, the Statistical Package for Social Sciences (SPSS), version 16.0 program was used for data analysis. To compare variables and association between $\mathrm{HBV} / \mathrm{HCV}$ seropositivity and risk factors, chi-square test and frequencies were used. The p-value, $\mathrm{P}<0.05$ was considered statistically significant.

\section{Results}

\subsection{Socio-demographic and socio-economic characteristics of study population}

In this study the socio-demographic and socioeconomic characteristics of the population were established to characterize the population. Table 1 summarizes the socio-demographics and socioeconomic characteristics of the population.

As shown in table 1, among 100 suspected patients, $34(34 \%)$ were males and $66(66 \%)$ were females. The mean age of the population was 45.54 and the age ranged between 21 and 87 years. The suspected patients according to age groups were 22(22 \%): 19-30,24(24\%): 29-40,16,16\%: 39-50 and $38(38 \%) \geq 50$. The majority of the suspected patients were married. The proportions of marital status were $76(76 \%)$ married, $13(13 \%)$ single, $2(2 \%)$ divorced and 9(9\%) widowers. Regarding education level, 29 (29\%) patients had completed primary studies,30 (30 \%) secondary studies, 25 (25\%) university studies and $16(16 \%)$ patients had never gone to school. concerning profession, 40(40\%) were private ,32(32\%) farmers $26(26 \%)$ civil servants and $2(2 \%)$ were students. In terms of socio-economic status of the patients, 62(62\%) were in third level,29(29\%) in the second level,5(5\%) in the first level and 4(4\%) in the fourth level. 
Table1: Socio-demographic and socio-economic characteristics of study population

\begin{tabular}{|c|c|c|c|}
\hline Variables & & Number & Percentages \\
\hline \multirow[t]{2}{*}{ Gender } & Male & 34 & $34 \%$ \\
\hline & Female & 66 & $66 \%$ \\
\hline \multirow[t]{4}{*}{ Age } & $19-30$ & 22 & $22 \%$ \\
\hline & $29-40$ & 34 & $34 \%$ \\
\hline & $39-50$ & 16 & $16 \%$ \\
\hline & $\geq 50$ & 38 & $38 \%$ \\
\hline \multirow[t]{4}{*}{ Marital status } & Married & 76 & $76 \%$ \\
\hline & Single & 13 & $13 \%$ \\
\hline & Divorced & 2 & $2 \%$ \\
\hline & Widower & 9 & $9 \%$ \\
\hline \multirow[t]{4}{*}{ Education } & No & 16 & $16 \%$ \\
\hline & Primary & 29 & $29 \%$ \\
\hline & Secondary & 30 & $30 \%$ \\
\hline & University & 25 & $25 \%$ \\
\hline \multirow[t]{4}{*}{ Socio-economic level } & 1 & 5 & $5 \%$ \\
\hline & 2 & 29 & $29 \%$ \\
\hline & 3 & 62 & $62 \%$ \\
\hline & 4 & 4 & $4 \%$ \\
\hline \multirow[t]{5}{*}{ Profession } & Farmer & 32 & $32 \%$ \\
\hline & Civil servant & 26 & $26 \%$ \\
\hline & Private & 40 & $40 \%$ \\
\hline & Student & 2 & $2 \%$ \\
\hline & & 100 & $100 \%$ \\
\hline
\end{tabular}




\subsection{Prevalence of $\mathrm{HBsAg}$ and $\mathrm{HCV}-\mathrm{Ab}$ infections}

In this study the prevalence of HBV and HCV were determined. Table 2 summarizes the
Prevalence of anti-HCV and HBsAg by age and gender.

Table 2: Prevalence of HCV-Ab \& HBsAg in suspected patients at RMH

\begin{tabular}{|c|c|c|c|c|c|}
\hline & & $\begin{array}{l}\text { Hepatitis B } \\
\text { Virus (HBV) }\end{array}$ & & $\begin{array}{l}\text { Hepatitis C } \\
(\mathrm{HCV}))\end{array}$ & \\
\hline Gender & $\begin{array}{l}\text { Frequency of } \\
\text { Patients }\end{array}$ & HBV Positive & Prevalence $(\%)$ & HCV Positive & Prevalence $(\%)$ \\
\hline Male & 34 & $6 / 34$ & $17.60 \%$ & $6 / 34$ & $17.6 \%$ \\
\hline Female & 66 & $11 / 66$ & $16.60 \%$ & $14 / 66$ & $21.2 \%$ \\
\hline $\begin{array}{l}\text { Average } \\
\text { prevalence }(\%)\end{array}$ & & 17 & $17 \%$ & 20 & $20 \%$ \\
\hline
\end{tabular}

Among 100 suspected patients 20 patients were tested positive for $\mathrm{HCV}-\mathrm{Ab}$ and the total prevalence was $20 \%$. Among 66 female patients, $14(21.2 \%)$ were HCV-Ab Positive and among 34 males, 6 male patients were positive for $\mathrm{HCV}-\mathrm{Ab}$ ( $17.6 \%$ ). Among 100 suspected patients, 17 were tested positive for HBsAg and the total prevalence was $17 \%$. Among 66 female suspected patients, 11(16.6\%) were HBsAg positive. Among 34 male suspected patients, 6 (17.6\%) were HBsAg positive.

The prevalence for $\mathrm{HCV}$ and $\mathrm{HBV}$ was high compared to the prevalence of $\mathrm{HCV}$ and $\mathrm{HBV}$ in Sub-Saharan region, which is $2-14 \%$. The fact that most of the patients were suspected for HBV and $\mathrm{HCV}$ infection could explain why the HBV and $\mathrm{HCV}$ prevalence was high.

In contradiction to the hypothesis that HBV infection could be higher than that of $\mathrm{HCV}$, the prevalence of $\mathrm{HCV}$ was found to be higher than that of HBV among the suspected patients (HCV,20\% > HBV, 17\%). This could be explained by the fact that HCV progress much slowly and that symptoms may appear after many years so that a person can be suspected and that HBV progresses quicker than $\mathrm{HCV}$ and can lead to mortality much quicker than HBV. Furthermore, the presence of HBV vaccine could also explain why the HCV was higher in prevalence than HBV.

\subsection{Risk factors for $\mathrm{HBV} \& \mathrm{HCV}$ and their association with $\mathrm{HBV} \& \mathrm{HCV}$ infections}

During the study, several risk factors for HBV and $\mathrm{HCV}$ in patients at $\mathrm{RMH}$ were reported. The association of socio-demographic, socio-economic, medical-related and behavioral related risk factors and HBV \& HCV infections was also determined.

\subsubsection{Socio-demographic, socio-economic risk factors and HCV at RMH}

During this study, different socio-demographic and socio-economic risk factors for $\mathrm{HCV}$ were determined. The table 3 summarizes sociodemographic, socio-economic and their association with HCV.

Socio-demographic risk factors such as age, gender, marital status, education, socio-economic and profession were determined. The frequencies were gender (Male:17.6 \%, Female:21 \%,), age (8.3 \%: 29-40, $12.5 \%$ : 39-50, $42.1 \%$ : $\geq 50$ ), marital status (Married:14/76(18.4 \%), single:1/14,7.1 \%, widow(er): 5/8, $62.5 \%$ ), education: Primary: 8/29 (27.5\%), Secondary:7/30, $23.3 \%$, University:1/24(4.1\%), Socio-economic level:1/5(20\%), 2:8/29,27.5\%,3:11/62(17.7\%) and profession (Farmer:2/32,6.25\%, Civil servant; 10/26,38.4\%, Private:8/40, 20\%).

Among 34 male suspected patients, 6 (17.6\%) were $\mathrm{HCV}-\mathrm{Ab}$ positive and Among 66 female participants, $14(21.2 \%)$ were HCV-Ab Positive. The distribution of $\mathrm{HCV}-\mathrm{Ab}$ prevalence across age groups was 2 (8.3\%): 29-40,2 (12.5\%):39-50 and $16(42.1 \%) \geq 50$ years. In the age $19-30$ there was 
no participants positive for HCV-Ab. In this study, Chi-square test revealed that only age and marital status were significant risk factors for HCV (Age , $p$ $=0.001$, Marital status, $p=0.01$ ).

Among 38 suspected patients in the older age group ( $\geq 50), 16(42.1 \%)$ of them were positive for $\mathrm{HCV}-\mathrm{Ab}$. HCV was lower in the age groups $<50$ which was probably due to low rate of participation in the younger age groups $(<50)$.

There was no evidence of difference between $\mathrm{HCV}$ prevalence in males $(6,17.6 \%)$ and females $(14,21.2 \%) \quad(\mathrm{p}=0.67)$. There was no statistical evidence for Education, socio-economic level and profession to be associated with $\mathrm{HCV}$.

Table 3 : Socio-demographic, socio-economic risk factors and HCV at RMH Hepatitis C Virus

\begin{tabular}{|c|c|c|c|c|c|c|c|}
\hline & & & $(\mathrm{HCV})$ & & Test & & \\
\hline $\begin{array}{l}\text { Social- } \\
\text { demographic } \\
\text { factors }\end{array}$ & & $\begin{array}{l}\text { Frequency } \\
\text { of Patients }\end{array}$ & $\begin{array}{l}\text { HCV } \\
\text { Positive }\end{array}$ & $\begin{array}{l}\text { Prevalence } \\
(\%)\end{array}$ & $\begin{array}{l}\text { Chi- } \\
\text { square } \\
\left(\mathrm{X}^{2}\right)\end{array}$ & $\begin{array}{l}\text { Degree of } \\
\text { freedom } \\
\text { (df) }\end{array}$ & p.value \\
\hline Gender & Male & 34 & 6 & $17.6 \%$ & 0.178 & 1 & 0.673 \\
\hline & Female & 66 & 14 & $21.2 \%$ & & & \\
\hline & $19-30$ & 22 & 0 & $0 \%$ & 17.389 & 3 & 0.001 \\
\hline Age (Years) & $29-40$ & 24 & 2 & $83 \%$ & & & \\
\hline & $39-50$ & 16 & 2 & $12.5 \%$ & & & \\
\hline & $\geq 50$ & 38 & 16 & $42.1 \%$ & & & \\
\hline & Married & 76 & 14 & $18.4 \%$ & 11.096 & 3 & 0.001 \\
\hline Marital status & Single & 14 & 1 & $7.1 \%$ & & & \\
\hline & Divorced & 2 & 0 & $0 \%$ & & & \\
\hline & Widow(er) & 8 & 5 & $62.5 \%$ & & & \\
\hline & No & 17 & 4 & $23.5 \%$ & 5.183 & 3 & 0.159 \\
\hline Education & Primary & 29 & 8 & $27.5 \%$ & & & \\
\hline & Secondary & 30 & 7 & $23.3 \%$ & & & \\
\hline & University & 24 & 1 & $4.1 \%$ & & & \\
\hline Social- & 1 & 5 & 1 & $20 \%$ & 2.032 & 3 & 0.566 \\
\hline $\begin{array}{l}\text { economic } \\
\text { Level }\end{array}$ & 2 & 29 & 8 & $27.5 \%$ & & & \\
\hline (Ubudehe) & 3 & 62 & 11 & $17.7 \%$ & & & \\
\hline & 4 & 4 & 0 & $0 \%$ & & & \\
\hline & Farmer & 32 & 2 & $6.25 \%$ & 5.457 & 3 & 0.141 \\
\hline Profession & $\begin{array}{l}\text { Civil } \\
\text { servant }\end{array}$ & 26 & 10 & $38.4 \%$ & & & \\
\hline & Private & 40 & 8 & $20 \%$ & & & \\
\hline & Students & 2 & 0 & $0 \%$ & & & \\
\hline
\end{tabular}

\subsubsection{Medical related risk factors and $\mathrm{HCV}$ at RMH}

During this research, medical related risk factors for $\mathrm{HCV}$ were determined. The medical

related risk factors and their association with $\mathrm{HCV}$ are summarized in table 4 . 
Table 4 : Medical Related Risk factors and their association with HCV at RMH Hepatitis C Virus (HCV) Test

\begin{tabular}{|c|c|c|c|c|c|c|c|}
\hline $\begin{array}{l}\text { Medical } \\
\text { related } \\
\text { factors }\end{array}$ & & $\begin{array}{l}\text { Frequency } \\
\text { of Patients }\end{array}$ & $\begin{array}{l}\mathrm{HCV} \\
\text { Positive }\end{array}$ & $\begin{array}{l}\text { Prevalence } \\
(\%)\end{array}$ & $\begin{array}{l}\text { Chi-square } \\
\left(\mathrm{X}^{2}\right)\end{array}$ & $\begin{array}{l}\text { Degree of } \\
\text { freedom } \\
\text { (df) }\end{array}$ & p.value \\
\hline \multirow{2}{*}{$\begin{array}{l}\text { History of } \\
\text { blood } \\
\text { transfusion }\end{array}$} & Yes & 4 & 1 & $25 \%$ & 2.754 & 1 & 0.098 \\
\hline & No & 96 & 19 & $19.7 \%$ & & & \\
\hline \multirow{2}{*}{$\begin{array}{l}\text { Surgical } \\
\text { treatment }\end{array}$} & Yes & 32 & 7 & $21.8 \%$ & 0.103 & 1 & 0.748 \\
\hline & No & 68 & 13 & $19.1 \%$ & & & \\
\hline \multirow{2}{*}{$\begin{array}{l}\text { Dental } \\
\text { treatment }\end{array}$} & Yes & 59 & 15 & $25.4 \%$ & 2.966 & 1 & 0.085 \\
\hline & No & 41 & 5 & $12.1 \%$ & & & \\
\hline \multirow{2}{*}{$\begin{array}{l}\text { Medical field } \\
\text { blood } \\
\text { esposure }\end{array}$} & Yes & 7 & 1 & $14.2 \%$ & & 1 & 0.695 \\
\hline & No & 93 & 19 & $20.4 \%$ & 0.154 & & \\
\hline \multirow{2}{*}{$\begin{array}{l}\text { Hospital in } \\
\text { the last } 2 \\
\text { years }\end{array}$} & Yes & 25 & 7 & $28 \%$ & 1.658 & 1 & 0.198 \\
\hline & No & 75 & 13 & $17.30 \%$ & & & \\
\hline
\end{tabular}

Medical related risk factors such as blood transfusion history, surgical treatment, dental treatment, medical blood exposure and hospitalization were reported. The frequencies were $1 / 4,25 \%$ for blood transfusion, $7 / 32(21.8 \%)$ for surgical treatment, $15 / 59(25.4 \%)$ for dental treatment,1/7(14.2\%) for blood exposure and $7 / 25(28 \%)$ for hospitalization.

\subsubsection{Behavioral related risk factors and $\mathrm{HCV}$ at RMH}

Behavioral related risk factors for $\mathrm{HCV}$ were reported in this study. The behavioral related risk factors and their association with $\mathrm{HCV}$ are summarized in table 5.

Table 5: Behavioral related risk factors and $\mathrm{HCV}$ transmission

\begin{tabular}{|c|c|c|c|c|c|c|c|}
\hline \multicolumn{6}{|c|}{ Hepatitis C Virus (HCV) } & \multicolumn{2}{|l|}{ est } \\
\hline $\begin{array}{l}\text { Behavioral } \\
\text { related risk } \\
\text { factors }\end{array}$ & & $\begin{array}{l}\text { Frequency } \\
\text { of Patients }\end{array}$ & $\begin{array}{l}\text { HCV } \\
\text { Positive }\end{array}$ & $\begin{array}{l}\text { Prevalence } \\
(\%)\end{array}$ & $\begin{array}{l}\text { Chi-square } \\
\left(\mathrm{X}^{2}\right)\end{array}$ & $\begin{array}{l}\text { Degree of } \\
\text { freedom } \\
\text { (df) }\end{array}$ & p.value \\
\hline \multirow[t]{2}{*}{ Ears pierced } & Yes & 24 & 2 & $8.3 \%$ & 2.686 & 1 & 0.101 \\
\hline & No & 76 & 18 & $23.6 \%$ & & & \\
\hline \multirow{2}{*}{$\begin{array}{l}\text { Injury with } \\
\text { used piercing } \\
\text { meterial }\end{array}$} & Yes & 58 & & $18.9 \%$ & 0.92 & 1 & 0.761 \\
\hline & No & 42 & 9 & $21.4 \%$ & & & \\
\hline \multirow{2}{*}{$\begin{array}{l}\text { Lived with } \\
\text { person who } \\
\text { has HCV }\end{array}$} & Yes & 14 & 3 & $21.4 \%$ & 0.021 & 1 & 0.885 \\
\hline & No & 86 & 17 & $19.7 \%$ & & & \\
\hline \multirow{2}{*}{$\begin{array}{l}\text { Had or been } \\
\text { treated for } \\
\text { STIs }\end{array}$} & Yes & 12 & 2 & $16.6 \%$ & 0.095 & 1 & 0.758 \\
\hline & No & 88 & 18 & $20.4 \%$ & & & \\
\hline
\end{tabular}

Behavioral related risk factors for $\mathrm{HCV}$ such as ear piercing, injury with used sharps, having had or treated for STIs and living with HCV infected person were determined. The frequencies for the risk factors were $2 / 24(8.3 \%)$ for ear piercing, $11 / 58(18.9 \%)$ for injury with used sharps,3/14( 21.4\%) for living with HCV infected person and $2 / 12(16.6 \%)$ for having or been treated for STIs. 
There was no evidence of association between behavioral related risk factors and $\mathrm{HCV}$ (p-value> 0.05 ). This could be the results of previous efforts made by sensitizing to the citizens about good care of hygienic and safe-care utensils and the use of preservatives to prevent STIs. (The results are presented in the table 5).

\subsubsection{Socio-demographic, socio-economic risk factors and $\mathrm{HBV}$ at RMH}

In this study, Different risk factors for HBV were reported. Table 6 summarizes the sociodemographic, socio-economic risk factors and their association with HBV.

Socio-demographic and socio-economic risk factors for HBV such as gender, age, marital status, education and profession were determined.
The frequencies were gender (Male: 6/34(17.6\%), Female: $11 / 66(16.6 \%$, age $(3 / 22,13.6 \%, 19-30,6 / 24(25 \%): 29-40$, 4/16(25\%):39-50, 4/38(10.5\%): $\geq 50)$, marital status, Married:15/76(19.7\%), Single: $2 / 14(14.2 \%)$, education (No:2/17(11.7\%), Primary: 9/29(32\%), Secondary: 3/30,10 \%, University: 3/24(12.5\%), Socio-economic level, 1: 2/5(40 \%) , 2: 4/29(13.7\%), 3: 10/62(16.1\%), 4:1/4(25\%) and profession: Farmer: $3 / 32(9.3 \%)$, Civil servant: 7/26(26.9\%), Private: 7/40(17.5\%).

In this study, there was no evidence of association between socio-demographic and economic risk factors with HBV (p-value $>0.05$ ).

Table 6: Socio-demographic, socio-economic risk factors and HBV at RMH Hepatitis B Virus (HBV)

\begin{tabular}{|c|c|c|c|c|c|c|c|}
\hline $\begin{array}{l}\text { Socio- } \\
\text { demographic } \\
\text { factors }\end{array}$ & & $\begin{array}{l}\text { Frequency } \\
\text { of Patients }\end{array}$ & $\begin{array}{l}\mathrm{HCV} \\
\text { Positive }\end{array}$ & $\begin{array}{l}\text { Prevalence } \\
(\%)\end{array}$ & $\begin{array}{l}\text { Chi- } \\
\text { square } \\
\left(\mathrm{X}^{2}\right)\end{array}$ & $\begin{array}{l}\text { Degree of } \\
\text { freedom } \\
\text { (df) }\end{array}$ & p.value \\
\hline \multirow[t]{2}{*}{ Gender } & Male & 34 & 6 & $17.6 \%$ & 0.015 & 1 & 0.902 \\
\hline & Female & 66 & 11 & $16.6 \%$ & & & \\
\hline \multirow{4}{*}{ Age (Years) } & $19-30$ & 22 & 3 & $13.6 \%$ & 2.61 & 3 & 0.456 \\
\hline & $29-40$ & 24 & 6 & $25 \%$ & & & \\
\hline & $39-50$ & 16 & 4 & $25 \%$ & & & \\
\hline & $\geq 50$ & 38 & 4 & $10.5 \%$ & & & \\
\hline \multirow{4}{*}{ Marital status } & Married & 76 & 15 & $19.7 \%$ & 2.525 & 3 & 0.471 \\
\hline & Single & 14 & 2 & $14.2 \%$ & & & \\
\hline & Divorced & 2 & 0 & $0 \%$ & & & \\
\hline & Widow(er) & 8 & 0 & $0 \%$ & & & \\
\hline \multirow{4}{*}{ Education } & $\mathrm{No}$ & 17 & 2 & $11.7 \%$ & 5.8 & 3 & 0.122 \\
\hline & Primary & 29 & 9 & $32 \%$ & & & \\
\hline & Secondary & 30 & 3 & $10 \%$ & & & \\
\hline & University & 24 & 3 & $12.5 \%$ & & & \\
\hline \multirow{4}{*}{$\begin{array}{l}\text { Social- } \\
\text { economic } \\
\text { Level } \\
\text { (Ubudehe) }\end{array}$} & 1 & 5 & 2 & $40 \%$ & 1.946 & 3 & 0.584 \\
\hline & 2 & 29 & 4 & $13.7 \%$ & & & \\
\hline & 3 & 62 & 10 & $16.1 \%$ & & & \\
\hline & 4 & 4 & 1 & $25 \%$ & & & \\
\hline \multirow{4}{*}{ Profession } & Farmer & 32 & 3 & $9.3 \%$ & 1.41 & 3 & 0.702 \\
\hline & $\begin{array}{l}\text { Civil } \\
\text { servant }\end{array}$ & 26 & 7 & $26.9 \%$ & & & \\
\hline & Private & 40 & 7 & $17.5 \%$ & & & \\
\hline & Student & 2 & 0 & $0 \%$ & & & \\
\hline
\end{tabular}




\subsubsection{Medical related risk factors and $\mathrm{HBV}$ at RMH}

Medical related risk factors for HBV were also determined during the study. Medical related risk factors and their association with HBV are presented in table 7 .

Medical related risk factors for HBV including blood transfusion history, surgical treatment, dental treatment, blood exposure, hospitalization and lack of vaccination were determined. The frequencies were $5 / 32(15.6 \%)$ for surgical treatment, $12 / 59(20.3 \%)$ for dental treatment, $2 / 7(28 \%)$ for blood exposure, $7 / 25(28 \%)$ for hospitalization and 17/82(20.7\%) for lack of vaccination.

The lack of vaccination against HBV was the only significant medical related risk factor for HBV ( $p=0.03$ ). Among 82 suspected patients who were not vaccinated $17(20.7 \%)$ of them were positive for HBsAg while among all 18 vaccinated participants none of them was infected, showing that vaccination is protective of $\mathrm{HBsAg}$.

The large proportion of unvaccinated people, which is a major risk factor, is probably due to that the vaccine against HBV in Rwanda is somewhat expensive, still not available on many health institutions for the citizens and that it has been introduced recently.

There was no evidence of association between Other medical related risk factors with the HBV infection. This is probably due to the improvement of medical care safety at different health institutions. (The results are presented in table 7).

Table 7: Medical Related Risk factors and HBV at RMH

\begin{tabular}{|c|c|c|c|c|c|c|c|}
\hline & & \multicolumn{2}{|c|}{ Hepatitis B Virus (HBV) } & \multicolumn{2}{|r|}{ Test } & & \\
\hline $\begin{array}{l}\text { Medical related } \\
\text { factors }\end{array}$ & & $\begin{array}{l}\text { Frequency } \\
\text { of Patients }\end{array}$ & $\begin{array}{l}\text { HBV } \\
\text { Positive }\end{array}$ & $\begin{array}{l}\text { Prevalence } \\
(\%)\end{array}$ & $\begin{array}{l}\text { Chi- } \\
\text { square } \\
\left(\mathrm{X}^{2}\right)\end{array}$ & $\begin{array}{l}\text { Degree of } \\
\text { freedom } \\
\text { (df) }\end{array}$ & p.value \\
\hline \multirow{2}{*}{$\begin{array}{l}\text { History of blood } \\
\text { transfusion }\end{array}$} & Yes & 4 & 1 & $0 \%$ & 1.078 & 1 & 0.299 \\
\hline & No & 96 & 19 & $17.7 \%$ & & & \\
\hline \multirow{2}{*}{$\begin{array}{l}\text { Surgical } \\
\text { treatment }\end{array}$} & Yes & 32 & 7 & $15.6 \%$ & 0.063 & 1 & 0.802 \\
\hline & No & 68 & 13 & $17.6 \%$ & & & \\
\hline \multirow[t]{2}{*}{ Dental treatment } & Yes & 59 & 15 & $20.3 \%$ & 1.332 & 1 & 0.248 \\
\hline & No & 41 & 5 & $12.1 \%$ & & & \\
\hline \multirow{2}{*}{$\begin{array}{l}\text { Medical field } \\
\text { blood esposure }\end{array}$} & Yes & 7 & 1 & $28.5 \%$ & 0.714 & 1 & 0.398 \\
\hline & No & 93 & 19 & $16.1 \%$ & 1.658 & & \\
\hline \multirow{2}{*}{$\begin{array}{l}\text { Hospitalization } \\
\text { in the last } 2 \\
\text { years }\end{array}$} & Yes & 25 & 7 & $28 \%$ & 3.313 & 1 & 0 \\
\hline & No & 75 & 13 & $13.3 \%$ & & & \\
\hline \multirow{2}{*}{ Vaccination } & Yes & 18 & 0 & $0 \%$ & 4.496 & 1 & 0.034 \\
\hline & No & 82 & 17 & $20.7 \%$ & & & \\
\hline
\end{tabular}

\subsubsection{Behavioral related risk factors and $\mathrm{HBV}$ at RMH}

Behavioral risk factors for $\mathrm{HBV}$ were also determined in this study. Behavioral related risk factors and their association with $\mathrm{HBV}$ are summarized in table 8 .
Behavioral related risk factors for HBV such as ear piercing, living with a person infected with HBV, treated or had STIs, and injury with sharps were determined in this study. The frequencies for the risk factors were $4 / 24(16.6 \%)$ for ear piercing,11/58(18.9\%) for injury with used sharps 
and piercing materials, $3 / 14(21.4 \%)$ for living with a person infected with $\mathrm{HBV}$ and $3 / 12(25 \%)$ for having had or having been treated for STIs.

In this study, there was no evidence for significant association between behavioral related risk factors and $\mathrm{HBV}$ ( $\mathrm{p}$-value $>0.05$ ). This could also be explained by recent efforts made in Rwanda by sensitizing to the citizens about good care of hygienic and safe-care utensils and the use of preservatives to prevent STIs. (The results are summarized in table 8).

Table 8: Behavioral Related Risk factors and $\mathrm{HBV}$ at RMH

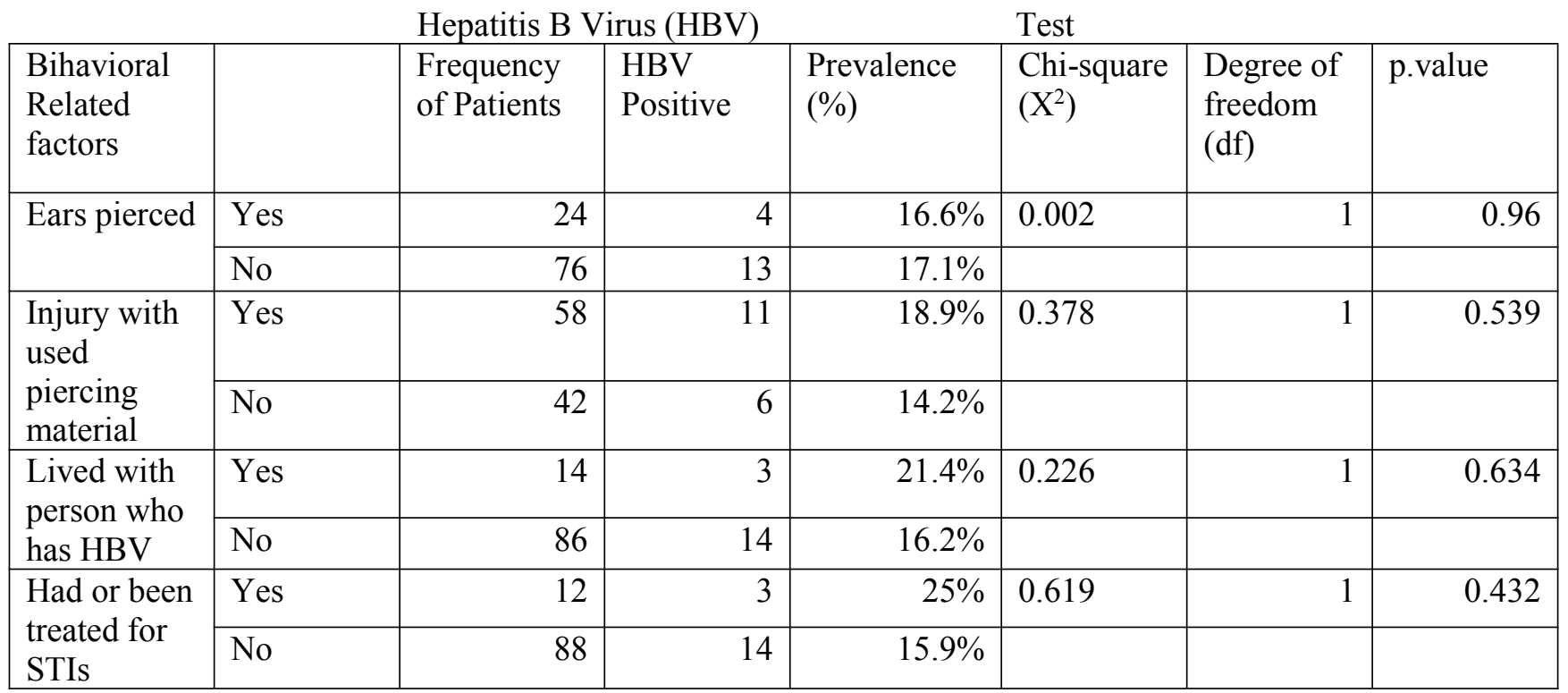

\section{Discussion}

\subsection{Prevalence of $\mathrm{HBV}$ and $\mathrm{HCV}$}

Hepatis C and B are common cause of liver disease world wide. Researchers mostly study these two viruses because of their capacity to co-infect within one person. In the present study, the prevalence of $\mathrm{HCV}$ was found to be higher than that of HBV among the suspected patients (HCV,20\% > HBV $17 \%$ ). This could be explained by the fact that $\mathrm{HCV}$ progress much slowly and that symptoms may appear after many years so that a person can be suspected and that HBV progresses quicker than $\mathrm{HCV}$ and can lead to mortality much quicker than HBV. Furthermore, the presence of HBV vaccine could also explain why the HCV was higher in prevalence than HBV. This study is not far from the study conducted in Sub-Saharan region, where the prevalence of HCV and HBVwere $2-14 \%{ }^{[17]}$. The fact that most of the patients were suspected for HBV and HCV infection could explain why the $\mathrm{HBV}$ and HCV prevalence was high.

\subsection{Factors associated with $\mathrm{HCV}$ and $\mathrm{HBV}$ infection}

Different risk factors associated with $\mathrm{HCV}$ and HBV infections were assessed and those factors incliding social demographic and economic factors, medical risk factors and behavioral risk factors.

\subsection{Demographic and economic risk factors of $\mathrm{HCV}$ and $\mathrm{HBV}$ infection}

Demographic and economic risk risk factors association was only seen on $\mathrm{HCV}$ infection for age and maritial status as risk factors with $\mathrm{x}^{2}=17.389$, $\mathrm{df}=3, \quad \mathrm{P}=0.001$ and $\mathrm{x}^{2}=11.096, \quad \mathrm{df}=1, \quad \mathrm{P}=0.011$ respectively. There no statistical significance for any factor with $\mathrm{HBV}$ infection. The highest $\mathrm{HCV}$ prevalence $5 / 8(62.5 \%)$ among widow(er)s is probably due exposure to extra marital sexual intercourses.

Higher prevalence for $\mathrm{HCV}$ in the older age group might have been due to that before 1992 high sensitive tests for $\mathrm{HCV}$ were not yet available, meaning that people might have been carriers of the infections for years infecting among others without knowing they were infected. Also, longer exposure 
to the inappropriate reuse of supplies such as use of injections for malaria by unqualified health care workers in last 15 or 20 years, could explain the higher prevalence in older aged participants. These findings correlate to other results in the reports on $\mathrm{HCV}$ infection's prevalence and risk factors such as reports from Antananarivo by Ramarokoto et al, from Nigeria by Ayolabi et al, from across Asia, Australia and Egypt by Sievertet al where by Gender was not a significant risk factor for the $\mathrm{HCV}$ infection but higher prevalence increased with older age ${ }^{[18,19]}$. The study conducted by belo et al showed that factors like education level, socioeconomic level and profession were significnant to the high prevalence of $\mathrm{HCV}$ infections, which makes contraction to this study where The insignificance of risk factors such as education level, socio-economic level and profession was reported, the same study of Belo et al reported that there is statistical significance between demographic and economic factors and the prevalnce of $\mathrm{HBV}$ infection which makes a contraduction to this study where level of education, socio-economic status and profession were reported insignificance to the prevalence of $\mathrm{HBV}^{[20]}$. (table 3,6).

\subsection{Medical risk factors associated withHCV and HBV infection at RMH}

Medical risk factors could be risk of not only Hepatitis but also other different infections. For $\mathrm{HCV}$ and $\mathrm{HBV}$ infections the assessed factors including transfusion history, surgical treatment, dental treatment, medical field exposure, Hospitalization in last 2 years, and vaccination. Results of the study show that there is no any medical related factor associated with $\mathrm{HCV}$ infection among participants. This is in contradiction with the study carried out by Rehermann, B., \& Nascimbeni ${ }^{[21]}$ where by risk factors such as previous procedure involving therapeutic injections, injectable drug use, dental procedure were significantly associated with $\mathrm{HCV}$ antibodies. This was probably due to the improved materialvigilance in different hospitals and health institutions while treating patients. (table 4).

However, vaccination has been a significantly show the association with $\mathrm{HBV}$ infection among participants with $\mathrm{X}^{2}=4.496, \mathrm{df}=1, \mathrm{P}>0,05, \mathrm{P}=0.034$. The large proportion of unvaccinated people, which is a major risk factor, is probably due to that the vaccine against $\mathrm{HBV}$ in Rwanda is somewhat expensive, still not available on many health institutions for the citizens and that it has been introduced recently.

The large proportion of unvaccinated people, which is a major risk factor, is probably due to that the vaccine against HBV in Rwanda is somewhat expensive, still not available on many health institutions for the citizens and that it has been introduced recently.

These findings are in accordance with other results in the study by Kateera et al done in Rwanda at University Teaching Hospital of Butare, where by lack of vaccination against $\mathrm{HBV}$ was a significant risk factor for $\mathrm{HBV}$ infection ${ }^{[22]}$. There was no evidence of association between Other medical related risk factors with the HBV infection. This is probably due to the improvement of medical care safety at different health institutions. (table7).

\subsection{Behevioral risk factors of $\mathrm{HCV}$ and $\mathrm{HBV}$ infections}

Behavioral factors were thought to be associated with HCV and HBV infections. Factors under considerration were ear pierced, injury with used sharps, Living with a person infected with $\mathrm{HCV}$ or HBV, and histotical treatment of STIs. However the findings showed that there is no association between both $\mathrm{HCV}$ and $\mathrm{HBV}$ infections(p-value $>0.05$ ). This could also be explained by recent efforts made in Rwanda by sensitizing to the citizens about good care of hygienic and safe-care utensils and the use of preservatives to prevent STIs. (table5\&8). Mentioned factors were not thought randomly even if results showed no significant, but they can be among cause but not main ones.ear pierced should be a source of HCV and HBV infections, it can be also classified among sharp instrument. Infection can invade during the process of ear piercing if one of person acting in this action is infected and passes infections to ear piercing object. Injury with used sharp are known spread infection if shared. Living with infected perosn facilitate infection spreading in different ways and historical treatment of sexual transmitted infections can be a risk of $\mathrm{HCV}$ and HBV infection due to immunosuppression. 


\subsection{Limitations}

This is study was limited by the time given to conduct it and only people coming at the hospital were considered.

\section{Conclusion and recommendation}

Assessment of HCV and HBV virus' infections and associated risk factors has been carried out on suspected patients attending RMH. There was no evidence of significant association of these risk factors with the HCV and HBV infections. No HBV and $\mathrm{HCV}$ co-infection was reported. Significant risk factors were marital status and older age for $\mathrm{HCV}$ while for HBV the lack of vaccination was the only significant risk factor. Mass education of the population and sensitization campaigns about the prevention of $\mathrm{HBV}$ and $\mathrm{HCV}$ infections is recommended to the government. Increasing accessibility and availability of HBV vaccine is urgently recommended to the Ministry of health. Citizens can get screened for HCV \& HBV and get vaccinated for $\mathrm{HBV}$. HCV and/or HBV patients can get tested for viral load and to adhere on given medications. Further researches including prospective studies regarding HCVand HBV can be done.

\section{Aknowledgement}

Gratitude thanks to Rwanda Military Hospital for their support in terms of sample collections and every thing done for this study to be possible. Deep appreciation to INES-Ruhengeri directorate of research to avail the time of conducting this study, it is through them that we have been able to do it. Many thanks to all biomedical laboratory sciences staff for their contribution to the quality of this work.

\section{References}

1 Batham, A., Narula, D., Toteja, T., Sreenivas, V., Puliyel, J. M. Systematic review and metaanalysis of prevalence of hepatitis B in India. Indian pediatrics, 2007,44(9), 663. [PMID:17921555]

2 Jarosławski, S.,Pai, M. Why are inaccurate tuberculosis serological tests widely used in the Indian private healthcare sector? A rootcause analysis. Journal of Epidemiology and Global Health, 2012, 2 (1), 39-50. DOI:10.1016/j.jegh.2011.12.001

3 McMahon, B. J., Alward, W. L., Hall, D. B., Heyward, W. L., Bender, T. R., Francis, D. P., Maynard, J. E. Acute hepatitis B virus infection: relation of age to the clinical expression of disease and subsequent development of the carrier state. journal of infectious diseases, 1985, 151 (4), 599-603. DOI: $10.1093 /$ infdis/151.4.599

4 Kirk, G. D., Lesi, O. A., Mendy, M., Akano, A. O., Sam, O., Goedert, J. J.,Montesano, R. The Gambia Liver Cancer Study: Infection with hepatitis $\mathrm{B}$ and $\mathrm{C}$ and the risk of hepatocellular carcinoma in West Africa. Hepatology, 2004, 39 (1), 211-219. DOI: 10.1002/hep.20027

5 Cacoub, P., Renou, C., Rosenthal, E.,Cohen, P., Loury, I., Loustaud-Ratti, V.,Veyssier, P. (n.d.). Extrahepatic Manifestations Associated with Hepatitis C Virus Infection: A Prospective Multicenter Study of 321 Patients. Medicine, 2000, 79 (1), 47-56. DOI:10.1097/00005792200001000-00005

6 Irshad, M., Dhar, I. Hepatitis C virus core protein: an update on its molecular biology, cellular functions and clinical implications. Medical Principles and Practice,2006, 15 (6), 405-416. DOI:10.1159/000095485

7 Karoney, M. J.,Siika, A. M. Hepatitis C virus (HCV) infection in Africa: a review. Pan African Medical Journal,2013, 14 (1), 87-114. DOI:10.11604/pamj.2013.14.44.2199

8 Guidotti,L.G.,Rochford, R.,Chung, J.,Shapiro, M., Purcell, R.,Chisari, F. V. Viral clearance without destruction of infected cells during acute HBV infection. Science, 1999, 284 (5415),

825-829.

DOI: $10.1126 /$ science.284.5415.825

9 Stockdale, A.J.,Geretti, A. M. Chronic hepatitis B infection in sub-Saharan Africa: a grave challenge and a great hope. Transactions of The Royal Society of Tropical Medicine and Hygiene, 2015, 109 (7), 421-422. DOI: $10.1093 /$ trstmh/trv044

10 Maini, M. K., Boni, C., Lee, C. K., Larrubia, J. R., Reignat, S., Ogg, G. S.,Williams, R. The role of virus-specific $\mathrm{CD} 8+$ cells in liver 
damage and viral control during persistent hepatitis B virus infection. The Journal of experimental medicine, 2000, 191 (8), 12691280. DOI:10.1084/jem.191.8.1269

11 Alter, M. J. Epidemiology of viral hepatitis and HIV co-infection. Journal of hepatology,2006, 44 (1), 6-9. DOI: 10.1016/j.jhep.2005.11.004

12 Rana, J. S., Khan, A. R., Haleem, A. A., Khan, F. N., Gul, A.,Sarwari, A. R. Hepatitis C: knowledge, attitudes and practices among orthopedic trainee surgeons in Pakistan. Annals of Saudi medicine, 1999, 20, (5-6), 477-479. DOI: 10.5144/0256-4947.2000.477

13 Te, H. S.,Jensen, D. M. Epidemiology of hepatitis $\mathrm{B}$ and $\mathrm{C}$ viruses: a global overview. Clinics in liver disease, 2010, 14 (1), 1-21. DOI: $10.1016 /$ j.cld.2009.11.009

14 Peng, X. E.,Lin, J. Y., Lin, W. S.Meta-analysis of case-control studies on the dual infection of hepatitisB and $\mathrm{C}$ virus in carcinogenesis of hepatocellularcarcinoma in China.Chinese Journal of Cancer Prevention and Treatment, 2008. DOI: $10.1038 /$ sj.bjc.6602333

15 Parkin, D. M., Sitas, F., Chirenje, M., Stein, L., Abratt, R., Wabinga, H. Part I: Cancer in Indigenous Africans - burden, distribution, and trends. The lancet oncology,2008, 9 (7), 683692. DOI: $10.1016 / \mathrm{S} 1470-2045(08) 70175-\mathrm{X}$

16 Ayolabi, C. I., Taiwo, M. A., Omilabu, S. A., Abebisi, A. O., Fatoba, O. M. Sero-prevalence of hepatitis $\mathrm{C}$ virus among blood donors in Lagos, Nigeria. African journal of Biotechnology,2006, 5 (20), 75-83.
17 Madhava V , Burgess C, Drucker E. Epidemiology of chronic hepatitis $\mathrm{C}$ virus infection in sub-Saharan Africa. Lancet Infect Dis,2002, 8 (3), 293-302. [PMID :12062995]

18 Ramarokoto , C. E., Rakotomanana, F., Ratsitorahina, M., Raharimanga, V., Razafindratsimandresy, R., Randremanana, R., Rakoto-Andrianarivelo,M. \& Soares, J. L. Seroprevalence of hepatitis $\mathrm{C}$ and associated risk factors in urban areas of Antananari. infectious diseases, 2008, 81 (1), 1. DOI: $10.1186 / 1471-2334-8-25$

19 Sievert, W., Altraif, I., Razavi, H. A., Abdo, A., Ahmed, E. A., AlOmair, A. \& Elshazly, M. A systematic review of hepatitis $\mathrm{C}$ virus epidemiology in Asia, Australia and Egypt. Liver International,2011，31 (2), 61-80. DOI: 10.1111/j.1478-3231.2011.02540.x

20 Belo, A.C. Prevalence of Hepatitis B Virus Markers in Surgeons in Lagos, Nigeria. East African Medical Journal,2000, 77, 283-285. [PMID:12858922]

21 Rehermann, B.,Nascimbeni, M. Immunology of hepatitis B virus and hepatitis $\mathrm{C}$ virus infection. Nature Reviews Immunology,2005, 5 (3), 215229. DOI: $10.1038 /$ nri1573

22 Kateera, F.,Walker, T. D.,Mutesa, L.,Mutabazi, V., Musabeyesu, E., Mukabatsinda, C., Bizimana, P., Kyamanywa, P., Karenzi,B Orikiiriza, J. T. Hepatitis B and C seroprevalence among health care workers in a tertiary hospital in Rwanda. Transactions of the Royal Society of Tropical medecine and Hygiene, 2015, 109 (3), 203-208. DOI: $10.1093 / \mathrm{trstmh} / \mathrm{trv} 004$ 